\title{
The Mound Bayou Demonstrator. Black Memory at the Margins and the Means of Cultural Production
}

\section{Janet Kong-Chow}

\begin{abstract}
"The archive has always been a pledge, and like every pledge [gage], a token of the future. To put it more trivially: what is no longer archived in the same way is no longer lived in the same way. Archivable meaning is also and in advance codetermined by the structure that archives. It begins with the printer."
\end{abstract}

\section{- Jacques Derrida, "Archive Fever: A Freudian Impression"1}

This essay begins with a printer, in both senses of the word: the printer as person, and the printer as object. It is, as Derrida rightfully steers us, a deliberate privileging of these two interpretations over what might be more conventionally seen as being fundamental to archival research, the printed object. In many ways, to arrive at this particular region of interest - the Mississippi Delta - in the period of time between emancipation and the first Great Migration (1916-1940), is to confront not a wealth of archival material from and about this moment, but the profound silences in the archives.

Historians rightfully note that Black print culture in the American South had to overcome particularly arduous obstacles and hostile circumstances, from its earliest beginnings during the era of slavery. In Mississippi, as one example, law and custom decreed that enslaved persons were not allowed to learn to read or write, and at any Black assembly - including religious gatherings - white persons were required to also be present. It was, furthermore, illegal to train 
any Black persons as typesetters. ${ }^{2}$ The relative scarcity in surviving copies of Black periodicals makes it even more difficult to formally outline a history, let alone fully discern the "culture" part of Black print culture. But what if we heed Rodney G.S. Carter's insistence that archives are practices of power, and a reflection of the powerful in society? Carter calls for archivists to "allow for multiple narratives to fill some of these gaps, to make users aware of the silences, and to attempt to understand and respect the choice of certain groups to keep their silence." "What happens to "Black print culture" when the printed material is lost to us? Why and how was it lost?

At the core of this line of inquiry, the "center" as we typically understand it has been displaced. What we know about lost periodicals often comes from external accounts, either not directly involved with the actual printing of the paper, or outside the community a newspaper served. Yet we know without the physical preservation of copies that these newspapers undoubtedly existed, that they circulated widely in one or more places, and that residents read it and discussed it. In other words, for the existence of every periodical there was an imagined and real audience, movement and circulation.

What about an editor and his press can we piece together with the artifacts left behind? More importantly, what can we speculate about the impact his press and published works had on the community, Black readers in the South, and perhaps even readers on a national scale? If, as Pierre Nora writes, "imagination invests [the archive] with symbolic aura," what happens when that archive in part becomes imaginary, or trace? And if "the sacred is invested in the trace that is at the same time its negation," we should contemplate the implications of theorizing the trace, particularly in ways that can make a tangible impact on the communities who did not leave in the First and Second Great Migrations (1940-1970), the ones who stayed behind and remain there today. "The South is a disaster and it is also a miracle," writes Imani Perry. Of her home state Alabama, she observes that "organizers have literally never stopped fighting. But the nation's eyes haven't thawed enough to see it." "The same can be said about Mississippi. The imagined divide in this country between the North and the South remains one which relies upon caricatures of an irredeemable South and progressive North. This ahistorical narrative sustains a moral superiority which allows Northern critique of the South without palpably addressing histories of migration, intertwined economics, and settler colonial expansion. ${ }^{6}$

\section{The Black "Jewel of the Delta" and the Mound Bayou Demonstrator}

In her 1942 autobiography, Dust Tracks on a Road, Zora Neale Hurston begins with a brief reflection on her hometown:

I was born in a Negro town. I do not mean by that the black back-side of an average town. Eatonville, Florida, is, and was 
at the time of my birth, a pure Negro town - charter, mayor, council, town marshal and all. It was not the first Negro community in America, but it was the first to be incorporated, the first attempt at organized self-government on the part of Negroes in America. ${ }^{7}$

Even today, we recognize the details Hurston privileges in her description of "a pure Negro town"- the need to specify a distinction between the undesirable "black back-side" of a segregated town, and a town created intentionally apart, separate from the forces of Jim Crow segregation and white supremacy; her emphasis on leadership positions - "charter, mayor, council, town marshal"occupied by Black people; the significance of self-government at a time when slavery was so newly a thing of the "past."

Naturally, towns like Eatonville occupy a significant place in the American imaginary, Black and white. There have been other all-Black towns which have drawn the attention of scholars, in particular the Nashoba Community in Tennessee, and Buxton (also known as the Elgin Settlement) in Ontario, Canada. ${ }^{8}$ However, these were white philanthropic experiments - no matter how strongly their benefactors felt they were acting with the best of intentions (uplifting formerly enslaved peoples, reducing racial tensions, etc.) - motivated by a steadfast belief in racial segregation, even permanent emigration. In fact, Fanny Wright, founder of Nashoba, envisioned the community as a preliminary phase within the process of gradual emancipation, the end goal being eventual transport to settlements in Liberia or Haiti. ${ }^{9}$

In Mississippi, a town like Eatonville also existed (still exists today) and at the height of its commercial success and recognition it was upheld as "the Jewel of the Delta," a place of refuge at a time when race relations in the South, at the brink of Reconstruction's end and failure, were so tense even certain Black leaders were calling for the continuation of segregation in the name of safety. ${ }^{10}$ National attention faded over the mid-twentieth century as the town faced financial and economic decline, but in recent years there has been renewed interest in Mound Bayou. When the National Museum of African American History and Culture opened to the public in 2016, curators commemorated Mound Bayou with a replica of the town's state historical marker. Unique from comparable settlements of the time, Mound Bayou had a dedicated newspaper, the Mound Bayou Demonstrator, remarkable considering it was illegal in Mississippi to train any Black persons as typesetters. Whereas Eatonville, thanks to Hurston's groundbreaking novel, Their Eyes Were Watching God, retains a certain literary cache, Mound Bayou offers an unusually rich archive of preserved written material, invaluable foresight on the part of its founders. Intriguingly, this can partly be attributed to the town's indirect connections to one Jefferson Davis, president of the Confederacy, former senator of Mississippi, through his elder brother Joseph.

Highly influenced by the philosophies of Scottish social reformer Robert Owen, Joseph Davis ascribed to his paternalist ideologies on the master and 
worker relationship. Davis notably applied certain practices to the management of his own plantations, Hurricane and Brierfield - the latter of which he later "gifted" to his younger brother Jefferson around 1835. Joseph established a "form of self-government," a court that convened every Sunday, where

a slave jury heard complaints of slave misconduct and the testimony of the accused in his own defense. No slave was punished except upon conviction by this jury of his peers; Davis sat as the judge and seldom intervened except to ameliorate the severity of some of the sentences. ${ }^{11}$

These were the documented conditions under which Isaiah T. Montgomery, founder and leader of Mound Bayou, grew up. His father, Benjamin Montgomery, benefitted personally from Davis's encouragement that his enslaved workers hone and develop specialized skills that interested them. Moreover, they were allowed to keep profits earned through their skilled labor (by contracting their services to other enslaved persons, neighboring white residents, visitors who passed through on steamboats, and so forth). Taking advantage of the opportunities afforded him,

In 1842 [Montgomery] established a store on the plantation, selling dry goods and staple items to the slaves in exchange for the wood, chickens, eggs, and vegetables they produced on their own time... His store provided a convenient place for the entire community to buy goods; it saved a costly trip off the peninsula for the slaves and allowed the whites to buy a few luxuries without waiting for a visit to Vicksburg or Natchez. "The ladies of the family used to 'shop' at his store," a visitor recalled...He sold food and fuel to the steamboat captains who carried freight for the Bend. In time he became the actual business manager for Hurricane and, in the absence of the Jefferson Davises, for Brierfield as well. ${ }^{12}$

From a young age, Montgomery's two sons, Thornton and Isaiah, were involved in this family venture, their first taste of trade and commerce. Young Isaiah soon became Davis's valet and private secretary and was given unlimited access to his personal library.

While Joseph Davis governed his plantations with (what his contemporaries considered) an unique approach - and urged his brother Jefferson Davis to follow similar practices - Benjamin and Isaiah Montgomery were fundamentally not free, despite the exceptions afforded them, and they negotiated this paradox in particular ways that reveal their understanding of racial politics and autonomy. A Union officer who made Benjamin Montgomery's acquaintance in the years after the Civil War wondered, "I don't see how so inteligent [sic] a man could have consented to remain so long a Slave." ${ }^{.13}$ But a man as astute as Montgomery 
would have recognized the extreme precarity of the status of free Black residents in antebellum Mississippi. Suspicion of potential runaway slaves headed north would have severely hampered his ability to travel freely for personal business purposes; with written permission from Davis, Benjamin Montgomery had arguably greater mobility than some of his freed peers, albeit mediated by the paradox of his metaphysical status. Similarly, plantation economics and outright discrimination made it nearly impossible for independent Black farmers to thrive in the antebellum South, a reality the Montgomery family would acutely face in the immediate years following emancipation. It is understandably disorienting to interrogate the materiality of "freedom" for liberated Black southerners in juxtaposition with the "privileges" afforded Benjamin and Isaiah Montgomery (travel, capital accumulation, self-education, etc.) in light of both parties' subjection to intense surveillance and extralegal violence.

Here, I want to briefly make space to think about the work of historiography, national imaginary, and the American South, because many of the hard facts we can glean from Isaiah Montgomery's early life are inevitably yoked to his slave master, and the often-recuperative project of sanitizing U.S. chattel slavery. Elsewhere, Julia Michiko Hori identifies this "violent nostalgia" that we ought to be vigilant in parsing, "a sentimental longing for and regretful memory of a period," which "rehearses and preserves racial and economic disparities in the name of restoration." ${ }^{\prime 14}$ In so many accounts of Hurricane and Brierfield plantations there is extreme emphasis on humanizing Joseph Davis, so much so that we would not know of the Montgomerys and their astonishing family history were it not for an insistence on "good" slave masters. It is the Davis family's significance to hegemonic American history that landed any trace of the Montgomerys in the Library of Congress, and to grapple with this deeply unjust paradox is to sit with what Matt Richardson identifies as "irresolute and irresolvable" about Blackness, memory, and built archives. ${ }^{15}$ For Richardson, as well as Carter, what unsettles the archive is an opportunity and undoing. Resonant with what Saidiya Hartman pioneered as critical fabulation, ${ }^{16}$ the unfixedness Richardson details can be fertile ground for "movement and potential," and a call to rethink the questions we ask of subjects and their existence. ${ }^{17}$

After emancipation, the Montgomery family purchased the Davis Bend plantation from Joseph Davis and, for some time, more or less attempted to continue running it with their fellow newly freed peers. There was a brief period of success - in addition to increasing their output of cotton bales, in 1870 "Montgomery and Sons" took first prize for "the best single bale of long staple cotton" at the renowned St. Louis Fair and an international fair in Philadelphia six years later, where they were in competition with growers from places as far as Egypt and the Fiji Islands. ${ }^{18}$ They ran a successful merchant business, dealing in farm machinery and tools, even expanding to a Vicksburg location.

A confluence of factors contributed to the Montgomery family's decline at Davis Bend. Summarized briefly, unanticipated flooding in 1866 dealt a heavy blow to their cotton output and profits (and contributed to a massive insect and 
pest invasion the following year), combined with a worsening political climate as Reconstruction drew to an end. Ensuing legal battles between Joseph Davis's heirs and Jefferson Davis, who wished to reclaim his old plantation, Brierfeld, ${ }^{19}$ laid bare Joseph Davis's previous flexibility towards the Montgomerys' monthly mortgage payments. The final nail in the coffin was Benjamin Montgomery's death, amidst all their financial troubles and the loss of Davis Bend (remitted back to Joseph Davis's heirs). By 1880 Thornton and Isaiah had moved their families away to pursue new endeavors. ${ }^{20}$

Eldest son Thornton Montgomery had become "disillusioned with the prospects for Negroes in Mississippi” after his own family's experiences and decided to try his luck in the Western territories. ${ }^{21}$ He purchased land in the Dakota territory, where he flourished and steadily increased his holdings. By 1889, a Black newspaper in Minneapolis called him "the largest colored farmer in the Northwest." 22 He was unsuccessful, however, in persuading his younger brother Isaiah to leave Mississippi.

Isaiah Montgomery recognized the potential in newer frontiers, and when he was approached in 1887 by the Louisville, New Orleans, and Texas Railroad companies offering bargains on land along their new line running between Memphis and Vicksburg, he saw an opportunity. ${ }^{23} \mathrm{Up}$ until then, this territory, known as the Yazoo Delta, had seen very sparse settlement, let alone cultivation, but the expansion of railways quickly changed this. ${ }^{24}$ In the spring of 1887 , Montgomery and his wife, Martha, decided to sell all their Vicksburg interests and persuaded his cousin, Benjamin Green, to join them in buying 840 acres of land at a site roughly midway between Memphis and Vicksburg, which Montgomery christened Mound Bayou, for "the large Indian mound at its center where the two bayous converged." 25 They began advertising this new "colony" to Black residents in and around Vicksburg, and in 1888 set out to clear the land with a small group of "settlers." 26

In regards to naming, the settlement of Mound Bayou had an arguably greater awareness of its shared space with Indigenous heritage and presence than most, and their choice of term, "colony," has intriguing implications. Did they imagine themselves a European colonial equivalent, appropriating formerly white-owned land? Or was this an acknowledgement of prior Indigenous ownership and belonging, a primordial acknowledgment of what we today call settler colonialism? This may seem wildly speculative, but as Tiffany Lethabo King notes, recent research has uncovered rich archives from "an antebellum African American print culture in which Native Americans figured centrally in the nineteenth-century African American imagination. ${ }^{27}$ While the archive cannot definitively answer either question, we can still speculate relationally in the absence of evidence.

Like that of Eatonville, the story of the founding of Mound Bayou is imbued with a quality of myth-making: larger-than-life characters, the impossible becoming reality, and most importantly, the symbolism of its very existence to the rest of the nation. By 1900 the town and its residents were relatively stable and prosperous enough to form a newspaper, the Mound Bayou Demonstrator. 
A secular, non-religiously affiliated weekly periodical, it was rather unique in a time when the majority of southern Black printing and publishing came out of Black churches and fraternal organizations. ${ }^{28}$

Copies of the Demonstrator may no longer be extant today, but its existence remains a significant enough event-formerly enslaved citizens not only founded a town but also a newspaper - that it is still inevitably referenced in almost all firsthand accounts of Mound Bayou. Moreover, the very referential act of foregrounding its founding and operations is itself meaningful: it indicates a certain level of imaginary work being done that takes on a life beyond material existence. As Pierre Nora theorizes, an archive "becomes a lieu de mémoire only if the imagination invests it with symbolic aura. ${ }^{29}$ Our archive here- the Demonstrator - is missing, but we feel the absence of what should exist, what should have been preserved, in the form of periphery material. More specifically, we know enough about the printer and editor of the paper, Joseph Wayland (J.W.) Covington, to play bricoleur.

In his personal account of Mound Bayou's history, educator and editor Aurelius P. Hood identifies Covington as the printer and sometimes editor of the Demonstrator after a brief period of instability in leadership. Hood describes him as "a pre-eminently well qualified newspaper man, and as an artistic job and advertising designer his work is not surpassed by that done anywhere. ${ }^{" 30}$ It is perhaps in these passing moments of praise that we learn the most details about Covington's day-to-day responsibilities - certainly, this is the only account to ever make mention of his artistic and design skills, particularly in contribution to advertising and associative prestige. Hood implies that Covington's training, skills, and aesthetic sensibilities brought with him an elevated perception that had previously eluded the paper. ${ }^{31}$

Towards the end of the book, Hood includes a short biography of Covington that fills in many of the details of his life: he attended Columbus Normal Institute and later Rust University, one of the earliest historically

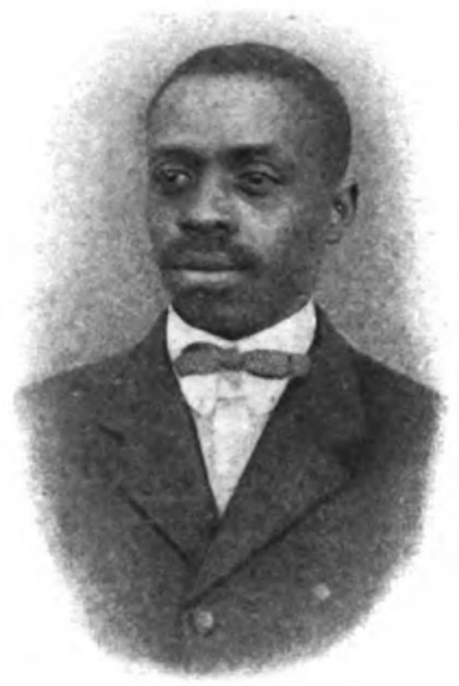

\section{J. W. COVINGTON}

Editor of "The Demonstrator," of Mound Bayou

Figure 1: Photographer unattributed, "The Pioneers of Mound Bayou," Century Illustrated Monthly Magazine 79 (1 November 1909), 395. 
Black universities founded in Mississippi; ${ }^{32}$ as a young boy he was "apprenticed to the trade of a printer," and he had previously worked for the Columbus Dispatch as well as "other influential white journals." ${ }^{33}$ Hood, speaking in regards to those who were involved in the development of the Demonstrator, writes:

They believed in Mound Bayou and believed that the work then being here accomplished was in every way worthy of being recorded and published for the enlightenment of the country as establishing the success of the colonization idea as exemplified in the life of this community. ${ }^{34}$

Hood's account of the paper's origins does not indicate Isaiah Montgomery's direct involvement, in editing or written contribution (though the paper would often print his speeches delivered elsewhere), but it would be remiss to overlook his influence, not only on the contents of the newspaper but also the town's understanding of its cultural significance and symbolism. The Montgomerys were voracious readers of print journalism and media, subscribing to a vast range of newspapers, journals, and magazines:

In addition to the Vicksburg papers, they regularly read the Cincinnati Times, the Chicago Tribune, and three New York papers - the Ledger, the Times, and the Tribune. Furthermore, unlike the Davis family, they read and contributed to Black newspapers such as the New Orleans Tribune immediately after the war, and the Louisianian and Frederick Douglass's New National Era in $1871 .^{35}$

During the period of time between 1865 and 1879 when Benjamin Montgomery and his family returned from Cincinnati (where they had fled temporarily when Union forces arrived) to live at Davis Bend, every Sunday was devoted to discussing and debating articles each family member had read over the course of the week. ${ }^{36}$

Besides Hood's account of Mound Bayou's newspapers, the earliest evidence of Covington's affiliation with the Demonstrator is a 1905 mention in another newspaper, the Oklahoma Safeguard, an African American weekly serial based in Guthrie, Oklahoma: "Mr. J.W. Covington of Mound Bayou, and business manager of the Mound Bayou Demonstrator, made a flying trip over here [Columbus, Miss.] on the 3rd visiting parents and friends and in the interest of his paper." ${ }^{37}$ In fact, per Hood's account, prior to joining the Demonstrator, Covington was employed by the Safeguard. ${ }^{38}$ In 1906 he is briefly mentioned again in the Safeguard, by Rev. William H. Jernagin (a Mississippi native himself) in a serialized account of his trip to the Delta region: "We found J.W. Covington doing his part at the Demonstrator office in getting out an up to-date progressive news paper [sic]." ${ }^{39}$ Throughout Covington's tenure at the Demonstrator, it appears that 
most regular contributors were given the title "editor," but Covington alone had the printing credentials, which might explain why he was the purported owner of the machinery and held on to it well after the newspaper ceased publication.

In terms of works published through his eponymous press or the Demonstrator press, a 1906 booklet titled, Report of the second annual convention of the Mississippi Negro Business League held in Jackson, Miss. June 13 and 141906 is the earliest extant document. Publisher details are listed as "Mound Bayou, Miss. : Demonstrator Job Print, J.W. Covington, mgr." He also appears to have had a lasting (publishing) relationship with town co-founder Isaiah Montgomery, printing at least two of Montgomery's books: Mound Bayou: A Town of Negroes Situated 104 Miles South of Memphis, 116 Miles North of Vicksburg, Is Very Near the Geographical Center of the Great Yazoo-Mississippi Delta (1914) ${ }^{40}$ and Our Great State, Mississippi: Tragic Sketch of the Past, the Great Turmoil of the Present, and the Wonderful Possibilities of the Future (1923). ${ }^{41}$

By 1910 the success of Mound Bayou was a nationally recognized story, and alongside the charismatic Montgomery and Charles Bank, founder and cashier of the Bank of Mound Bayou, Covington was interviewed by the New York Times for a one-page feature on the town, as well as a story for Century Illustrated Monthly Magazine. ${ }^{42}$ It is clear from that brief exchange in Century that Covington took his role seriously, and had earnestly contended with the historical weight of his actions and decisions (problematic as they might be in this age):

In an interview with the editor of "The Demonstrator," I was rude enough to express a doubt as to the future of the colony after the present generation of founders should have passed. The Editor took me to a window, and pointed to the groups of boys and girls who were hurrying past with neatly strapped books thrust under their arms.

"Do you think," he said, "that our boys and girls can go to and from our schools daily and not realize the benefit that comes from the industry and thrift that they see about them?" And then he added significantly: "What chance has the negro boy or girl who lives in the 'nigger quarters' of the cities? They learn to despise their race, and to think that they can never amount to anything, no matter how hard they work or how moral they are. The girls become prostitutes, and the boys gamblers or vicious idlers, at the age when the white boy and girl are still in school, through the idea that they are only 'niggers,' and that what they do does n't [sic] count. We are teaching them here that the negro counts."

And then the negro editor pulled out a copy of his paper, and pointed to a speech by a negro bishop.

"You give," the bishop said, addressing a mass-meeting of the stock-holders of the new cotton-seed oil mill- "you give 
to every negro that seeks admittance here equal opportunities to get a home, to get a business, and to get rich, if he can. The organization of this oil-mill will show the youth of our people the things of which we are capable, and will be inspiration to them to become fit for better things." 43

These moments are particularly interesting because as a printer and publisher Covington certainly had the means and resources to distribute his own writing, if he so desired. That he left behind no personal writings (that we know of or have survived) seems quite intentional. He certainly had strong opinions on the status of the race and a deep pride at all that they had accomplished in Mound Bayou, as demonstrated by these remarks. Moreover, it seems likely that he would have been reasonably well-connected, after working for several periodicals before arriving at the Demonstrator. A 1907 advertisement for the Voice of the Negro, a Chicago African American newspaper with roots in Atlanta, lists adulatory "opinions" ("blurbs," in modern day publishing parlance). Included in this mélange of quotes is praise from the "Mound Bayou Demonstrator." 4 Interpreting the Voice's choice of blurbs is an interesting exercise, one that paints a telling portrait of 1907 Chicago. Blurbs tend to be intentionally solicited from individuals and organizations who will appeal to or catch the attention of specific imagined audiences. The quotations chosen for this advertisement include respected and established papers of the times, such as the New York Age and the Springfield Republican, as well as endorsements from individuals hailing from states such as Tennessee, Georgia, Texas, Alabama, and, of course, Mississippi.

The deep connections forged between Northern cities and the agricultural South during the First and Second Great Migrations have been well documented by other scholars, and remain a ripe source of interest, especially in literary and cultural studies. ${ }^{45}$ There is ample evidence that a robust exchange existed between Mound Bayou and Chicago. The Chicago Defender makes numerous references to Montgomery and Banks, Mound Bayou's most public figures, but it also printed general quotidian updates on the lives of people who had moved to Chicago from Mound Bayou, and about their loved ones who remained behind in Mississippi. Society sections indicate Mound Bayou's well-to-do residents often traveled to Chicago to participate in large social events, and likewise, the Defender covered several major events that took place in Mound Bayou. ${ }^{46}$

Hood's account tells us the date of the Demonstrator's first issue-August 1, 1900 - but it is less clear how long the newspaper remained in print. The newspaper is listed in N.W. Ayer and Son's American Newspaper Annual and Directory for all yearly editions available through the Library of Congress from 1900 to 1919. ${ }^{47}$ One of two (known) existing souvenir programs commemorating the fiftieth anniversary of the colony's founding describes the Demonstrator as running for twenty years. ${ }^{48}$ What happened to the mysterious printer Covington after the demise of the Demonstrator? He is credited as the publisher of this very program, the "Souvenir Program of the $50^{\text {th }}$ Anniversary of Mound Bayou, Mississippi, 
July 11-17, 1937." Perhaps he remained active as a printer and publisher well into the 1930s (if not beyond). After all, Hood distinctly specifies that the press which was originally purchased to print the Demonstrator eventually "came into the hands of Mr. J. Wayland Covington, of Columbus, Miss., the present editor and manager." ${ }^{49}$ For this group of men who were so attuned to Black ownership and economic independence, Hood's deliberate use of "this property" to describe the printing press would seem to imply Covington purchased and became the owner of the machinery. Perhaps this can explain how he continued to make a living after his tenure as editor of the Demonstrator, as well as his involvement in the publication of the souvenir pamphlet in 1937. By then, according to that very pamphlet's copyright, he appears to have either moved away from Mound Bayou, or relocated his printing business to Shelby, Mississippi, another Bolivar County town just six miles from Mound Bayou. ${ }^{50}$

\section{Interpreting the Margins / In Search of the Printer}

What are we able to say about the contents of the Demonstrator? From the remarkably connected network of African American newspapers active during the Demonstrator's run we can deduce the nature of some of its articles. There is mention in 1904 of Roscoe C. Simmons's employment at the paper. Booker T. Washington's nephew, Simmons is best known for his later work at the Chicago Tribune, but he was born in Mississippi in 1881 and evidently worked for the Demonstrator prior to making a name for himself. ${ }^{51}$ Other papers reported on the Demonstrator's employment practices and the size of their press: "The Mound Bayou Demonstrator gives regular employment to six men and women of the race. It has a circulation of 3,000 and Editor A.P. Hood estimates that it is read by at least 10,000 persons each week." ${ }^{52}$

Additionally, Mound Bayouans were active in some debates and disputes beyond their immediate community, commenting in 1902 on "the controversy between the distinguished editors of Colored American and the Dallas Express" in favor of the Colored American, which reprinted an excerpt of their support. ${ }^{53}$ In other instances, when the Demonstrator published articles concerning events and happenings in other locales, the papers of those areas might make mention of the fact that they had been covered by the Demonstrator..$^{54}$ In many instances, the movement of individuals - whether for travel, business, or permanent migration - was also reported in these periodicals. Particularly during the years of Reconstruction and the First and Second Great Migrations, these newspapers were among the few resources available for the purposes of locating lost loved ones. Similarly, they promoted and reported on the social activities of the Black middle class, verging sometimes into the realm of gossip. For example, following Isaiah Montgomery's death, a Chicago newspaper reported rather salaciously on the arrests of his daughter and son-in-law, suggesting murder and foul play (charges never materialized and both were released without further investigation). ${ }^{55}$ 
Members of the Black press also weighed in on the politics of Mound Bayou's existence, and its status as an all-Black town. Papers such as the Indianapolis Freeman and the Washington Bee reacted favorably to the town's establishment in the first few years of its existence, and as time passed coverage shifted to a more utopic tone: the Southwestern Christian Advocate titled their 1910 profile of the town, "The Romance of Mound Bayou." 56 Overall most were positive, calling the venture "wonderful" and its founders "race builders," making note of how "prosperous" the town was, with its own bank and eventually its own cotton-seed oil mill. ${ }^{57}$

However, Mound Bayou was not without its detractors. The Horizon was critical of the decision to form a separate town, arguing that it only reinforced white supremacist sentiments that desegregation was impossible. "The Mound Bayouans," L.M. Hershaw wrote, "do not entertain the hope of becoming men among men, but are content to remain segregated and isolated. ${ }^{\prime 58}$ As Montgomery became more involved with national politics, his affiliation with Booker T. Washington and the Tuskegee Machine would also elicit heavy criticism, particularly from supporters of W.E.B. Du Bois (who, in fact, was the editor of the Horizon). Time has not judged Montgomery kindly, especially for his involvement in the 1890 Mississippi Constitutional Convention conference, where he delivered a speech in support of a poll tax and literacy test requirement to vote, which effectively disenfranchised the majority of Black voters in Mississippi.

Branded a "race traitor" and other similarly harsh epithets, Montgomery later privately admitted regret for the speech, but just as Desmond Jagmohan has recontextualized Booker T. Washington's political ideologies with the lived experiences of his time, we might extend this thinking towards Montgomery, as a key representative of the Tuskegee Machine in Mississippi. ${ }^{59}$ Many have focused on the contents of his 1890 speech, but as Neil R. McMillen has pointed out, by the time Montgomery was scheduled to deliver his speech, the conveners of the conference had already voted and approved the measure. ${ }^{60}$ Likewise, as the singular Black man invited to speak (and likely one of the few, if not the only Black man, in general attendance), Montgomery would have been keenly aware of not only the political risks of dissenting, but also the very real physical risks. Likewise, he would have recognized that no matter the words he delivered the decision had already been made. He might have gleaned from his own father's experience that in certain instances it was potentially beneficial to have the support of powerful white men. And the benefits he stood to gain from this accommodationist position were immunity and protection for Mound Bayou, founded just three years prior to the Convention.

This is not to say we should adopt an apologist revision of Montgomery's legacy_-I am not suggesting we paint a more forgiving account of his mistakes and missteps. There is likely an element of truth in accusations that his motives eventually devolved into self-interest and capital enrichment. However, it remains increasingly necessary that we revisit regions of the country where radical thought and protest manifested in modified ways. Racial oppression remains highly un- 
even from state to state, county to county, in some cases even neighborhood to neighborhood. To thoughtfully engage with what can often seem like frustratingly misguided pragmatism regarding race relations in the U.S., we must consider the material conditions that form such political ideologies. Individuals define and perform radical acts in accordance to the social restrictions within which they live. Sometimes the more appropriate interpretation of silence and inaction is not apathy, but survival.

Perhaps the most fitting example we can consider of this survival is the very act of creating Black print during the early years of Mound Bayou's existence. Though we know much about the circumstances and creation of the Demonstrator, we know much less about the people who made it possible. From the scant biographical details that remain of Covington's life, we know that he was born in Kosciusko, Mississippi and "apprenticed to the trade of printer while yet quite a boy." ${ }^{\circ 1}$ Again, an astonishing premise considering Mississippi law. To whom was he apprenticed? There is no documentation that can definitively prove it, but coincidentally, the editor of the Oklahoma Safeguard, C.A. Buchanan-Covington's employer prior to his arrival in Mound Bayou — began his publishing career in Kosciusko, as founder of the weekly Preacher and Teacher (1894-1904). There are conflicting epistolary accounts as to why Buchanan left (fled?) Mississippi, but all agree that he was driven out by the white mob. One version of events claims it was for printing an inflammatory editorial, but there are other letters which indicate it may have simply been because he was making a decent living and supporting his family well. ${ }^{62}$ In a letter seeking Booker T. Washington's help in the matter, Montgomery writes that Buchanan's success with Preacher and Teacher angered his white neighbors because they feared their Black sharecroppers and laborers would develop white-collar ambitions, depleting their supply of cheap labor, particularly at a time when they were losing many to northern migration. ${ }^{63}$

Whatever the truth, the reality remained that in certain parts of the country one could pay for being a Black printer with one's death, and Covington likely witnessed firsthand in Kosciusko what had happened to his mentor. Perhaps he was acquainted with other Black printers and editors who had not been as lucky as Buchanan.

\section{Emerging from the Archive}

It follows that after the challenges faced by Benjamin Montgomery during Reconstruction, his son Isaiah left Davis Bend with an intimate understanding of the deeply precarious nature of contracting the literal means of production - the cotton gin, the oil mill — as well as the risk associated with credit. It is significant, to my mind, that Isaiah Montgomery, raised with more privileges than the average enslaved person, who interacted with progressive (for their time) white southerners, still saw the most viable future as Mound Bayou. To that end, the men and women who founded and deeply invested in this settlement-fiscally 
and emotionally—had a sophisticated understanding of Black memory and preservation, particularly how both pertained to cultural production.

Despite protestations against allowing "any radical, nonsensical, and indiscreet policy to prevail," and by recognizing the soft power of newspapers and mainstream publicity, what the founders of Mound Bayou pursued as a means of preservation via print and publishing paralleled some of the most radical Marxian strategies of the time calling for cultural autonomy. ${ }^{64}$ Although they publicly eschewed some of the more controversial political debates of the time (especially those questioning relations between white and Black residents in the South), this turn towards owning the means of production was a shrewd appropriation of capitalism. Their term of choice for this new kind of place-a "colony" within a country that had forsaken them-opens up new lines of potential inquiry about space, and the ways in which memories of spaces take on new meaning and power over time.

Spaces can be socially constructed, and we owe this sociological turn to Henri Lefebvre's seminal text, The Production of Space. In it he offers three modes of spatialization: spatial practice, representations of space, and representational spaces. All three contribute to the production of space; the making of space, and "If space is a product, our knowledge of it must be expected to reproduce and expound the process of reproduction." ${ }^{965}$ Furthermore, "If space is produced, if there is a productive process, then we are dealing with history." ${ }^{" 66}$ Applied to Black cartographies, Katherine McKittrick reminds us that

The relationship between black populations and geographyand here I am referring to geography as space, place, and location in their physical materiality and imaginative configurations - allows us to engage with a narrative that locates and draws on black histories and black subjects in order to make visible social lives which are often displaced, rendered ungeographic. ${ }^{67}$

As it applies to Mound Bayou, spatial practice has been well represented in works that examine the decisions made in the physical creation of the town, the day-to-day life, the way that people organized themselves and for what purposes. There are deep material conditions to spatial practice which allow us to consider why, according to accounts in white newspapers, Isaiah Montgomery kept a room in his house that he reserved specifically for white visitors. ${ }^{68}$ As an inversion of Jim Crow segregation, it reduces the logics of such a practice to farce, despite having real, lived implications. When those who are spatially restricted create (unrestricted) space for themselves, it renegotiates the "center," forcing us to rethink what is considered "marginal," and why. A white bedroom in Mound Bayou ultimately demonstrates the impotence of white hierarchical delusion, once removed from the arteries which nourish it - in a space made free for all, a white visitor might willingly choose self-restriction under the guise of 
supremacy. The domesticity of the bedroom, as opposed to concerns over dining with Montgomery, or socializing with him inside his own home, reveals more about notions of hygiene, purity, and contagion that animate anti-Black racism in the U.S. ${ }^{69}$ It is not enough that the occupants of the room for the night are all white: the entire legacy of its occupancy, the accumulative history of who has slept in this room, is held up to a standard of racial purity.

Representations of space, as Lefebvre denotes, allow us to "identify what is lived and what is perceived with what is conceived," meaning this is the mode within which print and publishing live. ${ }^{70}$ This is often the hegemonic space of a society, the "mode of production." "It was the role of the Demonstrator to create representations of Mound Bayou-faithfully recording local events, the ways of the town, the people who inhabit it. Representational space, then, is the abstraction of space, such that the space itself is no longer the center. It is when the symbolism of the space has overtaken the reality of it, often long after its chronological existence: "Representational space is alive: it speaks. It has an affective kernel or centre." "72 This is where we find ourselves now, with the negative space of the Demonstrator. But representational space is ever-changing, and subject to the whims and attentiveness of people and societies.

I learned this lesson as I attempted to locate a copy of the Advance-Dispatch, a Mound Bayou Baptist periodical that published around the same time as the Demonstrator, hoping it might offer more clues to the town's print culture. Although the Library of Congress indicated this copy was held in one of Duke University's libraries it was nowhere to be found in their catalog. Disappointingly, I would later be informed that as of November 1993, when the Library of Congress last updated their Chronicling America project, the periodical was housed in the open stacks of Duke's main library - not, as I had previously assumed, in special collections, where it might have been preserved to some degree. Tellingly, it (and other newspapers) were dispersed or discarded "[i]n preparation for a series of building renovations," and while some were sent to the American Antiquarian Society, the Advance-Dispatch was not. It is a feeling of frustration every student of the archive has likely felt at one point or another. What felt priceless to me, an artifact of the past, a source of pride for those who produced and read it, had been deemed unimportant, or at least not important enough to be preserved (even digitally) for posterity. Who had made the call? The decision of which newspapers ought to be saved, or discarded? It felt as if I had been just barely too late.

So long as archives exist, in a dizzying array of forms, the question of curation undergirds their creation, expansion, and preservation. In the case of marginalized peoples or minoritized subjects, this becomes difficult because curation more often than not has to balance the hegemonic demands of societal value, which tend to overlook artifacts of the oppressed or subjugated. ${ }^{73}$ At the same time, curators must speculate upon what will gain cultural and/or historical significance in the future. In researching Mound Bayou and the Demonstrator, I visited numerous archives precisely because those in charge of curation did not 
see much significance in the town itself, and as a result, collections were split and dispersed amongst different institutions. The largest collection is housed at Emory University, and owes its existence to Milbourn J. Crowe, the late unofficial "town historian." 74 On numerous occasions, archivists and librarians casually dismissed the vast collection as being nothing more than "junk," suggesting to me that Crowe had been a "hoarder." Certainly, some objects interested me more than others, but there was still beauty in the quiet intimacy of possessions that reflected the lives of those born and raised in Mound Bayou. I wondered how many other valuable special collections originated from similar "hoarding," and why this label seemed like a signifier more so for the perceived hegemonic value of the objects. In other words, in a society that repeatedly reinforces white supremacy and the marginalization of otherness, how might we find new ways - new language - for discussing the curation of objects that find belated value? How might we consider the affective appreciation of future generations and future residents of Mound Bayou, in relation to the role of institutions, like universities, for the preservation of historically significant materials? ${ }^{75}$

To theorize on Black print and the Black press is to consider the production of space within a culture that considers whiteness as default - itself a production of a similar kind of space (the "mainstream" press) but controlled by a hegemonic class. It is a relationship Montgomery understood far too well, and his solution for prospering within white hegemony was to simply remove himself from that space entirely. The Horizon's critique of Mound Bayou had valid points, but more than a century has passed since it admonished the town's residents for failing to work towards racial harmony and integration, and still whiteness retains its cultural dominance. If we can acknowledge the truth in W.E.B. Du Bois's pronouncement, "as the South goes, so goes the nation," how do we rise to this challenge, this invitation, to rethink Southern history and its relationship to the rest of the country? The power of the Mound Bayou Demonstrator as representational space suggests we have yet to reconfigure the symbolism of our country as abstract space: the history of this nation, and the false whiteness of its origins and "center."

\section{Notes}

Special thanks to Dr. Kinohi Nishikawa, whose seminar inspired this work-your support and mentorship are immeasurable; I will always be at a loss for words to properly convey my gratitude. This research was generously supported by the Program in American Studies at Princeton University, and workshopped at the Arts in the Black Press During the Age of Jim Crow conference at Yale University. Thank you, Lucy Caplan and Kristen Turner, for your patience and trust. Lastly, I want to thank Jimmy L. Williams, owner of the Country Platter Restaurant in Cleveland, MS, for the priceless stories and memories of Mound Bayou, and the best peach cobbler my mama and I have ever had.

1. Jacques Derrida, “Archive Fever: A Freudian Impression,” trans. Eric Prenowitz, Diacritics 25 , no. 2 (1995): 18 .

2. Julius E. Thompson, The Black Press in Mississippi, 1865-1985 (Gainesville: University of Florida Press, 1993), 1.

3. Rodney G.S. Carter, "Of Things Said and Unsaid: Power, Archival Silences, and Power in Silence," Archivaria: The Journal of the Association of Canadian Archivists 61 (2006): 217. 
4. Pierre Nora, "Between Memory and History: Les Lieux de Mémoire," Representations, no. 26 (1989): 14.

5. Imani Perry, “As Goes the South, So Goes the Nation,” Harper's Magazine, July 2018.

6. My thinking here is influenced largely by what Perry observes in "As Goes the South, So Goes the Nation": "when you write about returning home, and home is a place that echoes with national wounds, you run the risk of making it seem as though home is frozen except when you, the expatriate, return. That kind of work often reeks of the egotism of the Northeastern writer-and the idea that the interpretation of everything worth knowing depends upon her."

7. Zora Neale Hurston, Dust Tracks on a Road (New York: HarperCollins, 2006), 1.

8. William and Jane Pease cover many of these towns in Black Utopia: Negro Communal Experiments in America (Madison: State Historical Society of Wisconsin, 1963), and for further reading on Buxton, see Dorothy Schwieder, Joseph Hraba and Elmer Schwieder, Buxton: A Black Utopia in the Heartland (Iowa City: University of Iowa Press, 2003).

9. Gail Bederman, "Revisiting Nashoba: Slavery, Utopia, and Frances Wright in America, 1818-1826," American Literary History 17, no. 3 (2005), 438.

10. Origins of this nickname are unclear. While some historians attribute it to the founders, many others claim President Theodore Roosevelt coined the term. Regardless, none provide any citations to primary sources.

11. Janet Sharp Shermann, The Pursuit of a Dream (Jackson: University Press of Mississippi, 1999), 12.

12. Ibid., 19.

13. Ibid., 21.

14. Julia Michiko Hori, "Berthing Violent Nostalgia: Restored Slave Ports and the Royal Caribbean Historic Falmouth Cruise Terminal," American Quarterly 68, no. 3 (2016), 689.

15. Matt Richardson, The Queer Limit of Black Memory: Black Lesbian Literature and Irresolution (Columbus: Ohio State University Press, 2013): 4.

16. Saidiya Hartman, "Venus in Two Acts," Small Axe 12, no. 2 (2008): 10-12.

17. Richardson, The Queer Limit of Black Memory, 5.

18. Sharp, Pursuit of a Dream, 151-52.

19. It is disputed that Jefferson Davis ever legally owned Brierfield; although within the Davis family it was referred to as belonging to Jefferson, in actuality Joseph never transferred the property deed to his younger brother.

20. Sharp, Pursuit of a Dream, 195-216.

21. Ibid., 219-20.

22. Ibid.

23. Ibid., 221.

24. Nan Elizabeth Woodruff, American Congo: The African American Freedom Struggle in the Delta (Cambridge, MA: Harvard University Press, 2003), 8.

25. Sherman, Pursuit of a Dream, 221

26. Ibid., 222.

27. Tiffany Lethabo King, The Black Shoals: Offshore Formations in Black and Native Studies (Durham, NC: Duke University Press, 2019), 13-14.

28. Thompson, Black Press in Mississippi, 7-10.

29. Nora, "Between Memory and History," 19.

30. Aurelius P. Hood, The Negro at Mound Bayou: being an authentic story of the founding, growth and development of the "most celebrated town in the South," covering a period of twentytwo years (Nashville: A.M.E. Sunday School Union, 1910), 30-31.

31. Ibid.

32. Founded in 1866 as Shaw College, formerly Shaw University (1870-1892), changed its name from Rust University to Rust College in 1915, as it is known today. See http://www.rustcollege.edu/about rust.html.

33. Hood, The Negro at Mound Bayou, 110.

34. Ibid., 29.

35. Shermann, Pursuit of a Dream, 167.

36. Ibid.

37. "Columbus Bureau," Oklahoma Safeguard (Guthrie, OK), 11 May 1905, http://gateway. okhistory.org/ark:/67531/metadc275391.

38. Hood, The Negro at Mound Bayou, 110.

39. "Jernagin's Trip South," Oklahoma Safeguard, 6 September 1906.

40. Isaiah T. Montgomery, Mound Bayou: A Town of Negroes...(Mound Bayou, MS: J.W. Covington, [1914]).

41. Isaiah T. Montgomery, Our Great State, Mississippi: tragic sketch... (Mound Bayou, MS: J.W. Covington, [1923]).

42. Thomas H. Arnold, "Ex-Slaves Dream of a Model Negro Colony Comes True," New York Times, 12 June 1910, SM5. 
43. Hiram Tong, "The Pioneers of Mound Bayou," Century Illustrated Monthly Magazine 79 (1 November 1909): 396. 76.

44. "Opinions of The Voice" (advertisement), Voice of the Negro, 4, no. 1, 1 February 1907,

45. St. Clair Drake and Horace R. Cayton, Jr.'s Black Metropolis: A Study of Negro Life in a Northern City (New York: Harcourt, Brace and Co., 1945) is perhaps the most obvious example; Steven Hahn's A Nation Under Our Feet: Black Political Struggles in the Rural South, from Slavery to the Great Migration (Cambridge, MA: Belknap Press of Harvard University Press, 2003) makes valuable contributions to this literature, as well as Wallace Best's Passionately Human, No Less Divine: Religion and Culture in Black Chicago, 1915-1952 (Princeton, NJ: Princeton University Press, 2007), for a study of religion over periods of migration. See also Isabel Wilkerson, The Warmth of Other Suns: The Epic Story of America's Great Migration (New York: Random House, 2010).

46. Henry Slaughter, "The North Side and Its Society," Chicago Defender, 7 May 1910, 3.

47. Years 1901-1904 and 1906-1909 are missing.

48. "History of Mound Bayou, Miss.," Souvenir Program of the 50 th Anniversary of Mound Bayou, Mississippi (Shelby, MS: Off Press of J.W. Covington, 1937), 32.

49. Hood, The Negro at Mound Bayou, 30.

50. Copyright, Souvenir Program of the 50 ${ }^{\text {th }}$ Anniversary of Mound Bayou, Mississippi (Shelby, MS: Off Press of J.W. Covington, 1937). 1904,4

51. "Mr. Roscoe C. Simmons...," The Colored American (Washington, D.C.), 19 March

52. R.W. Thompson, "Short Flights," Freeman (Indianapolis), 13 May 1911, 2.

53. "Some Generalities that Glitter," The Colored American, 3 May 1902, 2.

54. "Personals," St. Louis Palladium, 30 September 1904, 4.

55. "Eugene Booze and Wife Arrested; Charged with Murdering Isaiah T. Montgomery," Light and Heebie Jeebies, 13 August 1927, 14.

56. "Cobbstone and Chit Chat," Washington Bee, 26 November 1904, 5; "The Romance of Mound Bayou," Southwestern Christian Advocate, 7 July 1910, 1.

57. See "Wonderful Mound Bayou," Colored American Magazine 12, no. 6 (1 June 1907): 417; "Mound Bayou Colonists Race Builders," Bellingham Herald, 20 December 1909, 10; The Romance of Mound Bayou," Southwestern Christian Advocate, July 7, 1910, 1.

58. L.M. Hershaw,"The Spirit of Mound Bayou," Horizon: A Journal of the Color Line 6, no. 2 (1 July 1910): 9.

59. Desmond Jagmohan, "Booker T. Washington and the Politics of Deception," in African American Political Thought, A Collected History, eds. Melvin L. Rogers and Jack Turner (Chicago: University of Chicago Press, 2020), 167-91.

60. Neil R. McMillen, Dark Journey: Black Mississippians in the Age of Jim Crow (Urbana: University of Illinois Press, 1990), 39.

61. Hood, The Negro at Mound Bayou, 110.

62. "Buchanan, Charles Andrew," Who's Who of the Colored Race: A General Biographical Dictionary of Men and Women of Colored Descent, Volume One, 1915 (Chicago: Frank Lincoln Mather, 1915), 49.

63. Isaiah T. Montgomery to Booker T. Washington, 6 September 1904, in Booker T. Washington Papers, Volume 8, eds. Louis R. Harlan and Raymond W. Smock (Urbana: University of Illinois Press, 1979), 61-63.

64. Quotation from Arnold, "Ex-Slaves Dream of a Model Negro Colony Comes True," New York Times, SM5. For example, Antonio Gramsci's work on ideology, culture, and media, which would later deeply influence the Frankfurt School and British cultural studies.

65. Henri Lefebvre, The Production of Space, trans. Donald Nicholson-Smith (Oxford, UK: Blackwell, 1991), 36.

66. Ibid., 46.

67. Katherine McKittrick, Demonic Grounds: Black Women and the Cartographies of Struggle (Minneapolis: University of Minnesota Press, 2006), $\mathrm{x}$.

68. Tong, "The Pioneers of Mound Bayou," 395.

69. For further reading on the role of hygiene, contagion, and public health discourse in Jim Crow segregation, please visit the excellent web-based accompaniment to the 2001 documentary, Remembering Jim Crow. Firsthand accounts make this connection very clear: "The sign on the outside of the pool read: Hours 10am to $6 \mathrm{pm}$ Tuesday-Sat. Colored: Sunday from 1pm-5pm. After 5pm on Sunday, my grandfather would drain the pool (125,000 gal.) and on Monday everyone would grab buckets of liquid chlorine and scrub the entire pool. I asked my grandfather why we did this, and he said that the colored people were unclean and this would kill any bacteria that they would bring in." See http://americanradioworks.publicradio.org/features/remembering/public. html.

70. Lefebvre, The Production of Space, 38. 
71. Ibid., 39 .

72. Ibid., 42.

73. There is a larger discussion that can be had about a sub-category of collecting, that which fetishizes commodities as an indirect relationship of libidinal domination; the examples which come to mind are the relatively prodigious number of collections specializing in offensive antebellum objects trafficking in pervasive stereotypes, Japanese sword/katana collections, etc.

74. Milbourn J. Crowe papers, 1889-2005, Stuart A. Rose Manuscript, Archives, and Rare Book Library, Emory University.

75. These are vigorous debates in library sciences and archival studies. In "Of Things Said and Unsaid," Rodney G.S. Carter offers an excellent discussion of whether archivists ought to intervene or create their own archival materials to offset the marginalization of certain groups (224-25). However, because the archive reflects state power and hegemony, sometimes correcting an archive in this way can change perceptions of the "mainstream" for historians in the future (226). While there are inclusive approaches that can be attempted (actively seeking out and inviting marginalized groups to contribute to archives, for instance), what is most within our control as scholars is not to depend on new methods which can be introduced in archival methodology, but to re-train ourselves to better interpret silences and absences, and why they exist in the first place. This is the work that must first be done before archivists can ethically and knowledgably identify silences and "the presence of the marginalized within the records of the state and its apparatuses" (231). 